\title{
Effect of GR32191, a potent thromboxane receptor antagonist, on exercise induced bronchoconstriction in asthma
}

\author{
J P Finnerty, O P Twentyman, A Harris, J B D Palmer, S T Holgate
}

Immunopharmacology Group, Southampton General Hospital,

Southampton

SO9 4XY

J P Finnerty

OP Twentyman

$S$ T Holgate

Glaxo Group Research

Ltd, Greenford,

Middlesex UB6 $0 \mathrm{HE}$

A Harris

J B D Palmer

Reprint requests to:

Dr Finnerty

Accepted 23 November 1990

\begin{abstract}
Previous work suggests a role for mast cell derived mediators in exercise induced asthma. The contribution of newly generated contractile prostaglandins to exercise induced asthma was assessed by using a potent and orally active thromboxane $\left(T P_{1}\right)$ receptor antagonist, GR32191. The effect of $120 \mathrm{mg}$ GR32191 on exercise induced asthma was observed in 12 asthmatic subjects. For the exercise challenge the subjects performed six minutes of treadmill exercise, breathing dry air at a work load that had previously been shown to induce a fall in $\mathrm{FEV}_{1}$ of $25 \%$ or more from the pre-exercise baseline. No effect of GR32191 on pre-exercise baseline airway calibre was evident. There was no significant difference in the mean maximum percentage fall in $F E V_{1}$ from baseline after exercise between drug and placebo (placebo $30 \cdot 2 \%$, GR32191 day $31 \cdot 6 \%$ ). It is concluded that the thromboxane antagonist GR32191 has no effect on exercise induced asthma. This suggests that prostaglandins, including PGD, that act via the thromboxane receptor do not have an important role in exercise induced asthma.
\end{abstract}

Exercise induced bronchoconstriction in asthma is believed to be due, at least in part, to degranulation of airway mast cells, possibly
Subjects' characteristics, baseline values, and maximum responses to exercise challenge (expressed as \% fall from pre-exercise $F E V_{1}$ ) after placebo and GR32191

\begin{tabular}{|c|c|c|c|c|c|c|c|c|}
\hline \multirow[b]{3}{*}{$\begin{array}{l}\text { Subject } \\
\text { No }\end{array}$} & \multirow[b]{3}{*}{ Sex } & \multirow[b]{3}{*}{ Age (y) } & \multirow[b]{3}{*}{$\begin{array}{l}F E V_{1} \\
(\% \text { pred })\end{array}$} & \multirow[b]{3}{*}{$\begin{array}{l}\text { Daily } \\
\text { medication }\end{array}$} & \multicolumn{4}{|l|}{$F E V_{1}$} \\
\hline & & & & & \multicolumn{2}{|c|}{ Placebo day } & \multicolumn{2}{|c|}{ GR32191 day } \\
\hline & & & & & $l$ & $\%$ fall & $l$ & $\%$ fall \\
\hline 1 & $\mathbf{M}$ & 38 & 113 & $\mathrm{~S}, \mathrm{~B} 200 \mu \mathrm{g}$ & $4 \cdot 75$ & $45 \cdot 3$ & $4 \cdot 55$ & $37 \cdot 4$ \\
\hline 2 & $M$ & 45 & 89 & S & 4.00 & $21 \cdot 3$ & $3 \cdot 25$ & $32 \cdot 3$ \\
\hline 3 & $M$ & 32 & 80 & $S$ & $3 \cdot 75$ & $18 \cdot 7$ & $3 \cdot 15$ & $39 \cdot 7$ \\
\hline 4 & $\mathrm{~F}$ & 23 & 87 & D & $2 \cdot 75$ & $29 \cdot 1$ & $2 \cdot 70$ & $22 \cdot 2$ \\
\hline 5 & $\mathbf{M}$ & 37 & 65 & $S$ & $2 \cdot 15$ & $25 \cdot 6$ & $2 \cdot 05$ & $26 \cdot 8$ \\
\hline 6 & $\mathrm{M}$ & 19 & 97 & $\mathrm{~S}, \mathrm{~B} 400 \mu \mathrm{g}$ & $4 \cdot 50$ & $27 \cdot 8$ & 4.90 & $8 \cdot 2$ \\
\hline 7 & $M$ & 39 & 96 & S, B $200 \mu \mathrm{g}$ & $4 \cdot 00$ & $10 \cdot 0$ & $3 \cdot 70$ & 18.9 \\
\hline 8 & $\mathrm{~F}$ & 21 & 88 & $S$ & 2.95 & $32 \cdot 2$ & $3 \cdot 20$ & $21 \cdot 9$ \\
\hline 9 & $\mathrm{M}$ & 25 & 109 & $\mathrm{~S}, \mathrm{~B} 300 \mu \mathrm{g}$ & $4 \cdot 20$ & $40 \cdot 5$ & $4 \cdot 60$ & $28 \cdot 3$ \\
\hline 10 & $\mathbf{M}$ & 26 & 85 & $\mathrm{~T}, \mathrm{SC} 40 \mathrm{mg}$ & $3 \cdot 75$ & $44 \cdot 0$ & $3 \cdot 75$ & $38 \cdot 7$ \\
\hline 11 & $\mathbf{F}$ & 19 & 104 & $\mathrm{~S}$ & $4 \cdot 00$ & $50 \cdot 0$ & 4.00 & $45 \cdot 0$ \\
\hline 12 & $\mathrm{M}$ & 21 & 112 & $\mathbf{S}$ & $4 \cdot 20$ & $17 \cdot 9$ & $4 \cdot 20$ & $59 \cdot 5$ \\
\hline $\begin{array}{l}\text { Mean } \\
\text { (SEM) }\end{array}$ & & & & & $\begin{array}{c}3 \cdot 75 \\
(0 \cdot 22)\end{array}$ & $\begin{array}{l}30 \cdot 2 \\
(3 \cdot 6)\end{array}$ & $\begin{array}{c}3.67 \\
(0.24)\end{array}$ & $\begin{array}{l}31 \cdot 6 \\
(3 \cdot 9)\end{array}$ \\
\hline
\end{tabular}

$\star$ S-salbutamol; D-combined fenoterol and ipratropium bromide; T-terbutaline (all three taken as required); B-beclomethasone dipropionate; SC-sodium cromoglycate aerosol. All taken as required); B-beclomethasone dip as a result of transient hypertonicity of the airway lining fluid. ${ }^{12}$ The role of the mast cell has been suggested by studies showing that exercise induced asthma can be suppressed by prior administration of sodium cromoglycate and nedocromil sodium, and partially inhibited by selected $\mathrm{H}_{1}$ antihistamines. ${ }^{3-5}$

Placing hypertonic solutions in the airways has been shown to stimulate the generation and release in vivo of prostaglandin $\mathrm{D}_{2}$ $\left(\mathrm{PGD}_{2}\right){ }^{6}$ a potent bronchoconstrictor, ${ }^{7}$ in addition to releasing preformed mediators such as histamine. We have shown that the selective cyclo-oxygenase inhibitor flurbiprofen attenuates exercise induced asthma, and this is believed to be through reduction of the endogenous generation of prostanoids, including thromboxane $\mathrm{A}_{2}\left(\mathrm{TxA}_{2}\right)$ and $\mathrm{PGD}_{2}{ }^{5}$ Previous studies using indomethacin have failed to show any effect on exercise induced asthma. ${ }^{89} \mathrm{PGD}_{2}$ mediated contraction of human bronchial smooth muscle is thought to be mediated via a specific thromboxane $T P_{1}$ receptor. $^{10}$ The compound GR32191 is a potent orally active competitive TP receptor antagonist, which has been shown to protect the airways of patients with asthma against the bronchoconstrictor effect of inhaled $\mathrm{PGD}_{2}$ and to reduce the immediate bronchoconstrictor response to inhaled allergen. ${ }^{11}$ In this study we determined the direct contribution of contractile prostaglandins to the airway narrowing provoked by exercise, using GR32191 in a dose of $120 \mathrm{mg}$.

\section{Methods}

SUBJECTS

Twelve non-smoking asthmatic volunteers (nine male, mean age $28 \cdot 8$, range $19-45$ years) took part (table). All were known to have exercise induced asthma. None had had a respiratory tract infection or required any change in medication within a month of entering the study, and none had required oral corticosteroids within the previous six months. All had a baseline $\mathrm{FEV}_{1}$ of at least $60 \%$ of the predicted value on entry to the study, and all gave written informed consent. Before study visits inhaled beta ${ }_{2}$ agonists and sodium cromoglycate were withheld for at least six hours and inhaled corticosteroids for at least 12 hours. The study was approved by the Southampton University and hospitals ethical subcommittee. 
treadmill (P K Morgan Ltd, Chatham) while inspiring dry air at room temperature and atmospheric pressure from a 2001 Douglas bag via a mouthpiece connected to a two way valve. The volume of inspired air was measured with a Parkinson Cowan gas meter (P K Morgan Ltd) and the volume (BTPS) displayed on the monitor of a microcomputer.

The highest of three measurements of the forced expiratory volume in one second $\left(\mathrm{FEV}_{1}\right)$ was taken as the baseline value before exercise testing. Each exercise test lasted six minutes. Air in the Douglas bag was supplemented from an air cylinder as necessary. On completion of the exercise task single measurements of $\mathrm{FEV}_{1}$ were made at one, three, five, $10,15,20,25$, and 30 minutes. The gradient and speed of the treadmill were adjusted during practice tests so that the maximum fall in $\mathrm{FEV}_{1}$ from the pre-exercise level was $25 \%$ or more. The gradient and speed of the treadmill were constant for each subject for each exercise test during the study.

\section{PROTOCOL}

Before entry to the study a treadmill exercise task sufficient to induce at least a $25 \%$ fall in $\mathrm{FEV}_{1}$ from the level immediately before exercise was determined for each subject. The exercise study day visits were at least five and no more than 14 days apart. After the subject had rested for five minutes baseline $\mathrm{FEV}_{1}$ was measured, the highest of three technically satisfactory readings being used. Either GR32191 $120 \mathrm{mg}$ or matched placebo tablets were then administered, the order being randomised. One hour later the pre-exercise baseline $F E V_{1}$ was measured, and this was followed by a six minute exercise test. Measurements of $\mathrm{FEV}_{1}$ were made over the next 30 minutes. Any residual bronchoconstriction was reversed with inhaled salbutamol $200 \mu \mathrm{g}$.

\section{DATA ANALYSIS}

The maximum percentage fall in $\mathrm{FEV}_{1}$ from baseline, pre-exercise $\mathrm{FEV}_{1}$ values, and volume respired during exercise on the two study days were compared by the paired Student's $t$ test, significance being attributed at the $5 \%$ level. The power of the study to detect a change in the maximum percentage fall in $\mathrm{FEV}_{1}$ after exercise was calculated from standard statistical tables ${ }^{12}$; for this we used a standard deviation $(11.9 \%)$ derived from data from the placebo day and from a prestudy control day on the 12 subjects. This figure is consistent with the repeatability of exercise induced bronchoconstriction found by other workers. ${ }^{13}$

\section{Results}

The mean (SEM) FEV 1 values before and one hour after GR32191 were $3.69(0.22) 1$ before GR32191 and $3.67(0.24) 1$ one hour afterwards (NS). The mean baseline value of $\mathrm{FEV}_{1}$ immediately before exercise did not differ between the two study days $(3.75(0.22) v 3.67$ $(0 \cdot 24) 1)$. There was no significant difference in

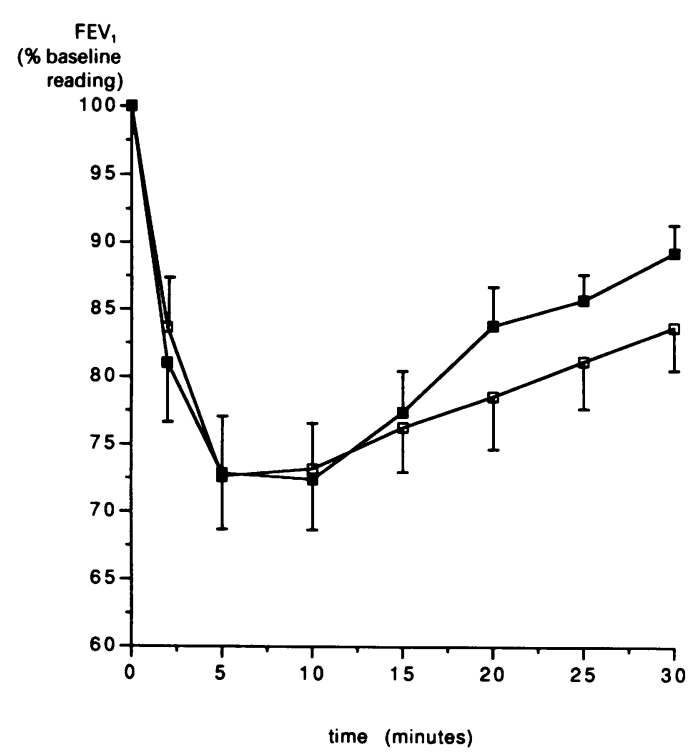

Time course of bronchoconstriction induced by exercise, expressed as mean percentage fall from pre-exercise baseline, after GR32191 (closed squares) and placebo (open squares).

ventilation over the six minutes of exercise on the two study days (215 (11) 1 on the placebo day $v 220$ (12) 1 on the GR32191 day).

The maximum percentage fall in $\mathrm{FEV}_{1}$ from the pre-exercise level after oral placebo was $30.2 \%(3.6 \%)$. Neither the maximum fall in $\mathrm{FEV}_{1}$ nor the time course of bronchconstriction differed significantly between placebo and GR32191 (figure and table). Neither a period effect nor a treatment-period interaction was evident. The study had a greater than $80 \%$ power of showing a $35 \%$ inhibition of the mean maximum percentage fall in $\mathrm{FEV}_{1}$.

\section{Discussion}

Using an antagonist of thromboxane $T_{1}$ receptors, we have attempted for the first time to separate the component of bronchoconstriction in exercise induced asthma resulting from release of contractile prostaglandins. GR32191 failed to have any significant effect on the magnitude or time course of exercise induced asthma. These data do not support a role for contractile prostaglandins, including mast cell derived $\mathrm{PGD}_{2}$, in exercise induced asthma.

Using human bronchial muscle preparations, Coleman and Sheldrick ${ }^{10}$ have shown that U-46619, a stable thromboxane mimetic, is the most potent prostanoid contractile agonist, being 383 fold and 628 fold more potent on a molar basis than $\mathrm{PGF}_{2 x}$ and $\mathrm{PGD}_{2}$. As the competitive antagonist $\mathrm{AH} 23848$ displaced the dose-response curves for all these prostaglandins to a similar degree they suggested that the prostaglandins mediate their bronchoconstrictor effect via the same receptor, the thromboxane prostaglandin receptor $\left(\mathrm{TP}_{1}\right){ }^{14}$ Armour et $a l^{15}$ found that GR32191, an analogue of $\mathrm{AH} 23848$, potently inhibited contractions induced by $\mathrm{PGF}_{2 \alpha}$ and U-46619 in human bronchial rings, and also protected 
against the contractile but not the relaxant effect

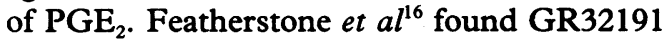
to be a potent antagonist in vitro of human airway smooth muscle contraction by $\mathrm{PGD}_{2}$, $\mathrm{PGF}_{2 \alpha}, \mathrm{PGF}_{9 \alpha}, \mathrm{PGF}_{9 \alpha, 11 \beta}-\mathrm{PGF}_{2}$, and $\mathrm{U}_{466191 .}$ GR32191 was the most potent of the thromboxane antagonists we studied, and was as potent in protecting against $\mathbf{P G D}_{2}$ induced contraction as against U466191 induced contraction, with an estimated two fold shift to the right of the dose-response curve at a concentration of the antagonist in the nanomolar range. No effect on methacholine induced contraction was observed at the highest concentration of GR32191 given. The specificity of GR32191 in vitro has been confirmed by other investigators; it does not protect against bronchial muscle contraction induced by carbachol, ${ }^{15}$ histamine, 5-hydroxytryptamine, or potassium chloride at concentrations of up to $0.1 \mathrm{mmol} .{ }^{17}$ Vasoconstriction by intravenous PGF $_{2}$ was ablated by a $20 \mathrm{mg}$ oral dose of GR32191, showing its activity in vivo on vascular contractile TP receptors. ${ }^{18} \quad \mathrm{PGD}_{2}$ induced bronchoconstriction was inhibited after $80 \mathrm{mg}$ of oral GR32191, with a mean 10 fold displacement of the dose-response curve to the right. ${ }^{11}$ Thus GR32191 is a potent and specific antagonist at the $T P_{1}$ receptor in man.

In the present study in patients with asthma, GR32191 failed to increase baseline FEV $_{1}$, indicating that contractile prostanoids probably have little influence on resting airway tone. All the subjects studied had an exercise induced fall in $\mathrm{FEV}_{1}$ and this did not differ significantly in magnitude or time course after GR32191 and placebo. These data suggest that contractile prostanoids have little or no role in the pathogenesis of exercise induced asthma.

This finding accords with the work of O'Byrne and Jones, ${ }^{8}$ who found no inhibition of exercise induced bronchoconstriction with indomethacine. It is, however, in conflict with our previous findings with flurbiprofen, a more potent cyclo-oxygenase inhibitor, which inhibits exercise induced bronchoconstriction, an effect attributed to inhibition of the generation of contractile prostaglandins acting on bronchial muscle. ${ }^{5}$ One possible explanation is that prostaglandins such as prostacyclin, a potent vasodilator generated during hyperventilation, ${ }^{19}$ may provoke airway narrowing by vascular engorgement and mucosal swelling. Such an effect would be unopposed by GR32191, which is selective for the $T P_{1}$ receptor. A vascular mechanism for exercise induced bronchoconstriction has been suggested by McFadden et $a l,{ }^{20}$ who have proposed that airflow limitation in these circumstances is a consequence of rebound hyperaemia, which causes swelling of the bronchial mucosa. Rapid intravenous infusions in asthmatic and normal subjects may induce bronchoconstriction, ${ }^{21}$ presumably by filling bronchial vessels. Four of our subjects were taking inhaled corticosteroids (table), and we might argue, despite the discontinuation of these drugs 12 hours before challenge, that this had inhibited the contribution of cyclo-oxygenase products to exercise induced asthma in these subjects. Although this is possible for prostanoids from non-mast cell sources, the production of $\mathrm{PGD}_{2}$ from mast cells is unaffected in vitro by corticosteroids. ${ }^{22}$

We have shown that GR32191 fails to inhibit bronchoconstriction induced by exercise in asthmatic subjects. Our findings do not support a role for contractile prostanoids acting through the $T P_{1}$ receptor in the genesis of exercise induced bronchoconstriction.

1 Anderson SD, Schoeffel RE, Black JL, Daviskas E. Airway cooling as the stimulus to exercise-induced asthma: a reevaluation. Eur J Respir Dis 1985;67:20-30.

2 Ingenito E, Solway J, Lafleur J, Lombardo A, Drazen JM, Pichurko B. Dissociation of temperature-gradient and evaporative heat loss during cold gas hyperventilation in cold-induced asthma. Am Rev Respir Dis 1988;138:540-6.

3 Patel KR, Kerr KW. Dose-response study of sodium cromoglycate in exercise induced asthma. Clin Allergy 1984;14:87-91.

4 Albazzaz MK, Neale MG, Patel KR. Dose-response study of nebulised nedocromil sodium in exercise-induced asthma. Thorax 1989;44:816-9.

5 Finnerty JP, Holgate ST. Evidence for the roles of histamine and prostaglandins as mediators in exercise-induced asthma: the inhibitory effect of terfenadine and flurbiprofen alone and in combination. Eur Respir J 1990;3: 540-7.

6 Gravelyn TR, Pan PM, Eschenbacher WL. Mediator release in an isolated airway segment in subjects with asthma. $A m$ Rev Respir Dis 1988;137:641-6.

7 Hardy CC, Robinson C, Tattersfield AE, Holgate ST. The bronchoconstrictor effect of inhaled prostaglandin $\mathrm{D}_{2}$ in
normal and asthmatic men. $N$ Engl $\mathrm{J} \mathrm{Med} \mathrm{1984;311:}$ normal

8 O'Byrne PM Jones GL. The effect of indomethacin on exercise-induced bronchoconstriction and refractoriness after exercise. Am Rev Respir Dis 1986;134:69-72.

9 Margolskee DJ, Bigby BG, Boushey HA. Indomethacin blocks airway tolerance to repetitive exercise but not to eucapnic hyperpnoea in asthmatic subjects. Am Rev Respir Dis 1988;137:842-6.

10 Coleman RA, Sheldrick RLG. Prostanoid-induced contraction of human bronchial smooth muscle is mediated by TP-receptors. Br J Pharmacol 1989;96:688-92.

11 Beasley RGW, Featherstone RL, Church MK, et al. Effect of a thromboxane receptor antagonist on $\mathrm{PGD}_{2}-$ and allergen induced bronchoconstriction. J Appl Physiol allergen induced

12 Machin D, Campbell MJ. Statistical tables for the design of clinical trials. Oxford: Blackwell, 1987:80.

13 Silverman M, Anderson SD. Standardisation of exercise tests in asthmatic children. Arch Dis Child 1972;47:882-9.

14 Coleman RA, Humphrey PPA, Kennedy I, Lumley P. Prostanoid receptors - the development of a working classification. Trends Pharmacol Sci 1984;5:303-6.

15 Armour CL, Johnson PRA, Alfredson ML, Black JL. Characterisation of contractile prostanoid receptors on human airway smooth muscle. Eur $J$ Pharmacol 1989;165:215-22.

16 Featherstone RL, Robinson C, Holgate ST, Church MK. Evidence for thromboxane receptor mediated contraction of guineapig and human airways in vitro by prostaglandin (PG) $D_{2}, 9 \alpha, 11 \beta-\mathrm{PGF}_{2}$ and $\mathrm{PGF}_{2}$. Naunyn-Schmiedebergs (PG) $\mathrm{D}_{2}, 9 \alpha, 11 \beta-\mathrm{PGF}_{2}$ and $\mathrm{PGF}_{2}$.

17 Lumley P, White BP, Humphrey PPA. GR32191, a highly potent and specific thromboxane $A_{2}$ receptor blocking drug on platelets and vascular and airways smooth muscle in vitro. Br J Pharmacol 1989;97:783-94.

8 Maconochie J, Kensington J, Lumley P. Evaluation of the vascular thromboxane $A_{2}$ receptor blocking activity of GR32191 in man [abstract]. Br J Clin Pharmacol GR32191 in

19 Gryglewski RJ, Korbut R, Ocetkiewicz A. Generation of prostacyclin by lungs in vivo and its release into the arterial circulation. Nature 1978;273:765-7.

20 McFadden ER, Lenner KA, Strohl KP. Postexertional airway rewarming and thermally induced asthma. $J$ Clin Invest 1986;78:18-25.

21 Gilbert IA, Winslow CJ, Lenner KA, Nelson JA, McFadden ER. Pulmonary obstruction in normals and asthmatics following intravenous fluid infusions to induce bronchial vasocongestion [abstract]. Am Rev Respir Dis 1989;139:A498.

22 Robin JL, Seldin D, Austen KF, Lewis RA. Regulation of mediator release from mouse bone marrow-derived mast cells by glucocorticoids. J Immunol 1986;135:2719-26. 